\title{
Physiological and Genetic Response Characteristics of Stenotrophomonas Rhizophila JC1 Under Heavy Metal Stress
}

Shangchen Sun

Lanzhou University of Technology

Kexin Zhang

Lanzhou University of Technology

Yamiao Wu

Lanzhou University of Technology

Yonggang Wang (D 412316788@163.com)

Lanzhou University of Technology https://orcid.org/0000-0003-3762-6421

Jixiang Chen

Lanzhou University of Technology

Feifan Leng

Lanzhou University of Technology

\section{Research Article}

Keywords: Stenotrophomonas rhizophila JC1, physiological response, genetic response, transport proteins, detoxification, efflux system

Posted Date: August 24th, 2021

DOI: https://doi.org/10.21203/rs.3.rs-749120/v1

License: () (7) This work is licensed under a Creative Commons Attribution 4.0 International License. Read Full License 


\section{Abstract}

In this study, the $\mathrm{Cu}^{2+}(120 \mathrm{mg} / \mathrm{L})$ and $\mathrm{Cr}^{6+}(80 \mathrm{mg} / \mathrm{L})$ removal rate of $S$. rhizophila JC1 reached at $79.9 \%$ and $89.3 \%$, respectively. Scanning electron microscopy showed that $\mathrm{Pb}^{2+}$ and $\mathrm{Zn}^{2+}$ had no obvious effect on cell structure, but the cells became smaller and brighter under $\mathrm{Cu}^{2+}$ stress, and many nanoparticles formed on the cell surface under $\mathrm{Cr}^{6+}$ stress. The physiological response analyses demonstrated that moderate change of membrane permeability was necessary for adsorption. FI-IR and EDS analyses showed that exopolysaccharides (EPS) and the replacement of basic elements (ie., C, 0) might be the main means of heavy metals adsorption by strain. In addition, 323 transport proteins were predicted in the genome of $S$. rhizophila JC1. Among them, two, six and five proteins of the cation diffusion facilitator, resistance-nodulation-division efflux and P-type ATPase families were respectively predicted. The expression of genes showed that the synergistic action of transport proteins played an important role in the process of adsorption. The comparative genomics analysis revealed that S. rhizophila JC1 has long-distance evolutionary relationships with other strains, but the efflux system of S. rhizophila JC1 contained the same types of metal transport proteins as other metal-resistant bacteria.

\section{Introduction}

Precipitating, chelating, or altering the oxidation state of various heavy metals by using microorganisms has become a hotspot of research and a topic of industrial application in the field of environmental remediation (Kang and So. 2016). To ensure normal growth and metabolism under heavy-metal stress, microorganisms have developed homeostatic systems by controlling the processes of intake, transport, and efflux of heavy metals (Ma et al.2009; Valencia et al. 2013).

Efflux is a main approach applied by bacteria to command metal ions transport to reduce intracellular metal concentrations. There are three recognized efflux systems that play crucial roles in the heavy metal detoxification by bacteria. The cation diffusion facilitator (CDF) family is ubiquitous in bacteria, archaea and eukaryotes (Paulsen and Saier 1997), and it transports heavy metals, including $\mathrm{Co}^{2+}, \mathrm{Cd}^{2+}, \mathrm{Zn}^{2+}$ and possibly $\mathrm{Ni}^{2+}, \mathrm{Cu}^{2+}$ and $\mathrm{Hg}^{2+}\left(\mathrm{Kambe}^{2012)}\right.$. $\mathrm{Lots}^{2}$ of members of the CDF family consist of 300-550 amino acids, which include six transmembrane domains, the regulatory cytoplasmic C-terminal domain and a histidine-rich region that may be a potential metal-binding site (Barber et al. 2016). The P-type ATPase, located on the plasma membrane, promotes the metal efflux system through hydrolysis (Arguello et al. 2011). It transfers substrates from the outside of the cell or the peripheral cytoplasm to the cytoplasm, as well as from the cytoplasm to the extracellular or peripheral cytoplasm through P-type ATPases (Hiraizumi et al. 2019). Simultaneously, owing to the stimulating effects of sulfhydryl compounds on the metal efflux activity, CPx-type ATPases may also use glutathione to expel metals from the cytoplasm (Meng et al. 2015). The transporter-dependent resistance-nodulation-division (RND) efflux system has been considered to play a crucial role in heavy-metal resistance of bacteria (Saier et al. 1994). In most cases, the gene adjacent to the encoded protein is the member of membrane fusion protein (MFP) family (Nagakubo et al. 2002). Along with the outer membrane factors (OMFs)(Maseda et al. 2002), three of these protein families form an excretion protein complex, which can excrete the matrix from the cytoplasm, cell membrane or periplasmic space through the outer membrane (Kim et al. 2011; Yang et al. 2014).

In this paper, the adsorption ability of $S$. rhizophila JC1 (CP050062) for $\mathrm{Cr}^{6+}, \mathrm{Cu}^{2+}, \mathrm{Pb}^{2+}$ and $\mathrm{Zn}^{2+}$ of different concentration was validated. Furthermore, the morphological feature of strain JC1 stressed by different heavy metals was observed through scanning electron microscopy (SEM), the element composition of heavy metals adsorbed on bacterial surface was analyzed by energy-dispersive X-ray spectroscopy (EDS) and the functional groups were analyzed by Fourier Transform Infrared Spectrometry (FT-IR). We also analyze the changes of membrane permeability and macromolecular before and after heavy metal adsorption to reveal the physiological response mechanism of adsorption. Moreover, to better understand the molecular mechanism of adsorption, heavymetal transporters were predicted by using the TCDB database, and representative genes were verified by qPCR.

\section{Materials And Methods}

\section{Cultivation of strain JC1}

The strain $\mathrm{JC} 1$ was respectively cultured in $\mathrm{LB}, \mathrm{LB}+\mathrm{Cu}^{2+}, \mathrm{LB}+\mathrm{Cr}^{6+}, \mathrm{LB}+\mathrm{Pb}^{2+}$ and $\mathrm{LB}+\mathrm{Zn}^{2+}$ liquid medium with the final concentration of metal ions were 0 , 40 , $80,120,160$ and $200 \mathrm{mg} / \mathrm{L}$. Each treatment was repeated three times.

\section{Metal ions removal efficiency evaluation}

The growth status of strain $\mathrm{JC} 1$ was evaluated by measuring the $\mathrm{OD}_{600}$ value after culturing for 24 hours. The removal efficiency was evaluated by measuring the metal ions residues in the culture medium with atomic absorption spectrometry. The removal efficiency (\%) was calculated as follows:

Removal efficiency $(\%)=\left(\mathrm{C}_{0}-\mathrm{C}_{1}\right) / \mathrm{C}_{0}$

Where $\mathrm{C}_{0}$ is the initial concentration of metal ions before adsorption, and $\mathrm{C}_{1}$ is the final concentration of metal ions after adsorption.

\section{Morphology, functional groups and element composition analyses}

The strain JC1 was respectively stressed with $80 \mathrm{mg} / \mathrm{L}$ of $\mathrm{Pb}^{2+}, \mathrm{Cr}^{6+}, \mathrm{Cu}^{2+}$ and $\mathrm{Zn}^{2+}$ for 24 hours and centrifugated at $8000 \mathrm{~g}$ for $10 \mathrm{minutes}$. The cell sediments were fixed in $2.5 \%$ glutaraldehyde for 2 hours and washed three times with deionized water. Then washed with alcohol and tertiary butanol in turn, the concentration of alcohol was $30,50,70,80,90,100 \%$, respectively. After that, the cells were re-suspended in tertiary butanol with the cell concentration was $1 \times 10^{5} \mathrm{CFU} / \mathrm{mL}$. Finally, the samples were dried before observed with scanning electron microscope (SEM, JSM-6701F) (Wang et al. 2021). 
The strain $\mathrm{JC} 1$ stressed at $80 \mathrm{mg} / \mathrm{L}$ of $\mathrm{Pb}^{2+}, \mathrm{Cr}^{6+}, \mathrm{Cu}^{2+}$ and $\mathrm{Zn}^{2+}$ were also collected for functional groups and element composition analysis. Cell sediments were collected by centrifugation at $10000 \mathrm{~g}$ for 10 minutes and dried at $45^{\circ} \mathrm{C}$. After that, the infrared absorption spectra in the range of $4000-400 \mathrm{~cm}^{-1}$ was measured by Fourier Transform Infrared Spectrometry (FT-IR) and screened by 325 meshes for Energy Dispersive X-ray spectroscopy (EDS) examination 『Wang et al. 2020区.

\section{The physiological response of S. rhizophila JC1 under different metal ions stress}

To reveal the physiological response mechanism of strain JC1 after heavy metal ions stress, membrane permeability and intracellular macromolecular (ie., protein, phospholipid, alkaline phosphatase) substances were analyzed. Each treatment was repeated three times.

\section{The physiological response of membrane permeability}

The cell outer membrane (OM) permeability of S. rhizophila JC1 under different metal ions stress was analyzed by the method described by Loh (Loh et al. 1984). The strain JC1 was respectively stressed with $0,40,80,120 \mathrm{mg} / \mathrm{L}$ concentration of $\mathrm{Pb}^{2+}, \mathrm{Cr}^{6+}, \mathrm{Cu}^{2+}$ and $\mathrm{Zn}^{2+}$ for $24 \mathrm{~h}$. After that, $\mathrm{N}-\mathrm{phenyl-1-}$ naphthylamine (NPN) solution with the final concentration was $10 \mu \mathrm{mol} / \mathrm{L}$ was added, then slowly oscillate at $37^{\circ} \mathrm{C}$ about 3 minutes. Finally, the fluorescence value was measured at excitation wavelengths was $350 \mathrm{~nm}$ and emission wavelengths was $440 \mathrm{~nm}$ with fluorescence spectrophotometer. Three repeated experiments were performed.

The cell inner membrane (IM) permeability of S. rhizophila JC1 stressed by different metal ions was analyzed by measuring the $\beta$-galactosidasea activity (Liu et al. 2004). The logarithmic phase cells that cultured in LB medium containing $2 \%$ lactose were collected and washed twice with $0.85 \% \mathrm{NaCl}$ solution, then respectively stressed with $0,40,80,120 \mathrm{mg} / \mathrm{L}$ concentration of $\mathrm{Pb}^{2+}, \mathrm{Cr}^{6+}, \mathrm{Cu}^{2+}$ and $\mathrm{Zn}^{2+}$ for $24 \mathrm{~h}$. Thereafter, O-Nitrophenyl- $\beta$-D-Galactopyranoside (ONPG) solution with the final concentration was $1.5 \mathrm{mM}$ was added, then slowly oscillate at $37^{\circ} \mathrm{Cabout} 3$ minutes. Finally, the absorption value was measured at $415 \mathrm{~nm}$ with Spectrophotometer. Three repeated experiments were performed.

\section{The physiological response of intracellular macromolecular}

The strain $\mathrm{JC} 1$ treated with $0,40,80,120 \mathrm{mg} / \mathrm{L}$ concentration of $\mathrm{Pb}^{2+}, \mathrm{Cr}^{6+}, \mathrm{Cu}^{2+}$ and $\mathrm{Zn}^{2+}$ was cultured to the logarithmic growth stage, then the cell culture medium was collected. The protein content was determined by the Bradford method, and measured with BSA as standard (Panja et al. 2008, Wang et al. 2021).

The strain $\mathrm{JC} 1$ treated with $0,40,80,120 \mathrm{mg} / \mathrm{L}$ concentration of $\mathrm{Pb}^{2+}, \mathrm{Cr}^{6+}, \mathrm{Cu}^{2+}$ and $\mathrm{Zn}^{2+}$ was also used for phospholipid analyses. 1, 6-Diphenyl-1,3,5Hexatriene (DPH) with the final concentration was $0.5 \mathrm{mM}$ was added into the cell culture medium, then diluted the mixture 15 times by $100 \mathrm{mM}$ CaCl ${ }_{2}$, incubated away from light for 40 minutes. Finally, the fluorescence value was measured at excitation wavelengths was $350 \mathrm{~nm}$ and emission wavelengths was $440 \mathrm{~nm}$ with fluorescence spectrophotometer. (Waschuk et al. 2001).

The chromogenic substrate p-nitrophenylphosphate (pNPP) was used to investigate alkaline phosphatase enzyme activity (Schlesinger 1989). The strain JC1 was initially cultured in tris-glucose medium to the logarithmic growth stage. Then washed three times with phosphorus-free tris-glucose before cultured in phosphorus-free tris-glucose solution at $37^{\circ} \mathrm{C}$ for 40 minutes. After that, the cell sediments were re-suspended in deionized water after washed, then treated with treated with $0,40,80,120 \mathrm{mg} / \mathrm{L}$ concentration of $\mathrm{Pb}^{2+}, \mathrm{Cr}^{6+}, \mathrm{Cu}^{2+}$ and $\mathrm{Zn}^{2+}$. Finally, the mixture involving $1.0 \mathrm{~mL}$ metal-laden bacteria and $2.0 \mathrm{~mL} \mathrm{pNPP}$ of $200 \mathrm{mM}$ were incubated at $37^{\circ} \mathrm{C}$ about 15 minutes. The absorbance at $420 \mathrm{~nm}$ was measured.

Three repeated experiments were performed of above experiments.

\section{Genomes}

The genomic protein sequences and 16S rRNA of S. rhizophila JC1 were obtained from whole-genome sequencing results. Corresponding sequences of other strains were obtained from NCBI (https://www.ncbi.nlm.nih.gov/).

\section{Transport protein classification and comparation}

Diamond software was used to compare the amino acid sequence of the target species by TCDB database and match genes of the target species with their corresponding functional annotation information. SWISSPROT and TrEMBL databases were used for function analyses. The phylogenetic relationship of 15 comparative strains was obtained by 16S rRNA sequences analysis (Rozycki and Nies 2009).

\section{Functional validation of predicted genes by qPCR}

To identify the function of transport proteins of $S$. rhizophila JC1 under four heavy metal ions stress, four genes (i e., $c z c D, c z c B, Z n t A, C u^{2+}$-exporting ATPase) were examined by quantitative real-time PCR (qPCR). The reverse-transcribed was carried out according to the instructions of Super RT Kit (TaKaRa). Each qPCR procedure was carried out according to the description by Novinscak and Filion (Novinscak and Filion 2011). The 16S rRNA and $\beta$-actin gene were used as an internal standard. Three rounds of independent qPCR reactions were used to verify the expression of each gene and the data were showed as arithmetic means \pm the standard deviation. The P-value less than 0.05 was considered to be statistically significant (Wang et al. 2020).

\section{Results And Discussion}

\section{Metal ions removal efficiency}


The toleration and adsorption to different metal ions of strain JC1 showed great difference. For instance, during S. rhizophila JC1 was respectively cultured in $\mathrm{LB}+\mathrm{Cu}^{2+}, \mathrm{LB}+\mathrm{Cr}^{6+}, \mathrm{LB}+\mathrm{Zn}^{2+}$ that the concentration of metal ions was $40 \sim 120 \mathrm{mg} / \mathrm{L}, 40 \sim 200 \mathrm{mg} / \mathrm{L}, 40 \mathrm{mg} / \mathrm{L}$ for 24 hours, there were no significant difference in $\mathrm{OD}_{600}$ value. However, during the concentration of $\mathrm{Zn}^{2+}$ and $\mathrm{Pb}^{2+}$ were increased to $160 \mathrm{mg} / \mathrm{L}$, the strain JC1 hardly grew. The adsorption efficiency was $79.8 \%$ when the concentration of $\mathrm{Cu}^{2+}$ was $120 \mathrm{mg} / \mathrm{L}^{-1}$, while it reduced to $26.1 \%$ when the concentration reached to $160 \mathrm{mg} / \mathrm{L}$. More interesting was that with the concentration was $40 \sim 200 \mathrm{mg} \cdot \mathrm{L}^{-1}$ of $\mathrm{Cr}^{6+}$, there had no significant suppression on the growth of bacteria, but only showed maximum adsorption efficiency of $89.3 \%$ when the concentration was $80 \mathrm{mg} / \mathrm{L}$. In terms of $\mathrm{Pb}^{2+}$ and $\mathrm{Zn}^{2+}$, the strain $\mathrm{JC} 1$ hardly showed adsorption ability (Fig. 1). Hence, this phenomenon indicated that the adsorption of metal ions by bacteria was selective, which was also suggested by Ye (Ye et al.2014)

\section{Analysis of cells structure under metal stress by SEM}

In this study, the morphological feature of strain JC1 comparison between metal ions stressed-cells and unstressed-cells was performed with SEM analysis. In different metal ions stress condition, different cell morphology was observed (Fig. 2). For unstressed-cells, the cell structure was intact, showed rod-shaped (Fig. 2a). However, the rod-shaped of $\mathrm{JC} 1$ after $\mathrm{Cr}^{6+}$ stress was almost impossible observed, there were crowds of particles gathered on the surface and the cells were wrapped in the membrane (Fig. 2b). In the case of $\mathrm{Cu}^{2+}$, cells showed shorter and brighter (Fig. $2 \mathrm{c}$ ). The change caused by $\mathrm{Pb}^{2+}$ and $\mathrm{Zn}^{2+}$ was similar. In brief, the surface of the JC1 became rougher, but the difference was that the cells condensed into clusters after $\mathrm{Zn}^{2+}$ stress (Fig. $4 \mathrm{~d} \&$ e).

The change of cell morphology was the result of bacteria response to heavy metal stress. The decrease in cell size may be due to dehydration of the cells under $\mathrm{Cu}^{2+}$ stressed and also may be explained as a negative response of bacteria against further uptake of metal by decreasing the area of contact with the $\mathrm{Cu}^{2+}$ (Mohite et al. 2018). The rough of cell surface might be interpreted as a strategy to accumulate more metal ions on the surface of cells as in case $\mathrm{Pb}^{2+}$ and $\mathrm{Zn}^{2+}$. For $\mathrm{Cr}^{6+}$, we speculated that due to the change of membrane permeability, a large amount of particles, formed through extracellular polysaccharides (EPS) binding with $\mathrm{Cr}^{6+}$, attached to the cell surface.

\section{Analysis of chemical structure under metal stress by FT-IR}

Studies had confirmed that the adsorption of heavy metals by bacteria is energy independent and can be mediated by functional groups (Zhang et al. 2017). In this study, the functional groups of strain JC1 for adsorption with four heavy metals was analyzed by Fourier transform infrared spectroscopy (FI-IR). Obviously, among four metal-laden samples, significant shifts of $\mathrm{C}-\mathrm{O}-\mathrm{C}$ and $\mathrm{C}=\mathrm{O}$ were observed after the treatment of $\mathrm{Cr}^{6+}$, significant shifts of $\mathrm{O}-\mathrm{H}$ was observed after the treatment of $\mathrm{Cu}^{2+}$ and $\mathrm{Zn}^{2+}$, significant shifts of $\mathrm{C}-\mathrm{O}$ was observed after the treatment of $\mathrm{Pb}^{2+}$ (Fig. 2f). According to the Fl-IR analysis, we suggested that the binding by EPS was one of the important way for heavy metal detoxification. In addition, the detoxification that depends on the functional groups of the bacteria and the valence state of metal ions is selective (Ye et al. 2014, Zhang et al. 2017).

\section{Analysis of element composition under metal stress by EDS}

Generally, non-metallic elements such O, C, Si and non-toxic metal elements such as $\mathrm{Ca}^{2+}, \mathrm{Fe}^{2+} / \mathrm{Fe}^{3+}$ were the basic elements to maintain normal growth and metabolism of microorganism. However, some toxic metals such as $\mathrm{Cr}^{6+}$ or $\mathrm{Pb}^{2+}$ will exist in the cells through sites replacement due to atomic radius, cell structure. The result of element composition analysis after metal ions stress was shown in Fig. 3. Obviously, the corresponding metal elements were increased in the bacteria when they were stressed by different metals. Moreover, the metal content is consistent with the adsorption efficiency. Further analysis we found that, $\mathrm{Cr}^{6+}$ and $\mathrm{Cu}^{2+}$ mainly replaced the $\mathrm{O}$ element, while the $\mathrm{Pb}^{2+}$ and $\mathrm{Zn}^{2+}$ mainly replaced the $\mathrm{C}$ element, this may be related to the radius of the metal.

\section{Analysis of physiological response of S. Ihizophila JC1 under different metal ions stress}

\section{Determination of cell membrane permeability}

The change of OM permeability under different heavy metal stress was shown in Fig. 4. Distinctly, the OM permeability of strain JC1 was significantly affected by the type and concentration of metal ions. What is more, its variation trend was positively correlated with the adsorption capacity of $\mathrm{Cr}^{6+}$ and $\mathrm{Cu}^{2+}\left(\mathrm{Fig}^{2} \mathrm{1}_{4}\right)$. However, it was interesting to note that the change induced by $\mathrm{Pb}^{2+}$ and $\mathrm{Zn}^{2+}$ were higher than $\mathrm{Cr}^{6+}$ and $\mathrm{Cu}^{2+}$, but the cell survival rate and adsorption capacity were contrary to this. Secondly, the higher the concentration of $\mathrm{Pb}^{2+}$ and $\mathrm{Zn}^{2+}$, the higher the change of OM permeability, but the cell survival rate and adsorption capacity were also contrary to this(Fig. 1ه4). We speculated that: 1 ): detoxification factors for $\mathrm{Cr}^{6+}$ and $\mathrm{Cu}^{2+}$ were more abundant compared with $\mathrm{Pb}^{2+}$ and $\mathrm{Zn}^{2+}$ in cells of strain $\left.\mathrm{JC} 1,2\right)$ : cells will die when the membrane permeability changes exceeds its self-repair ability.

Similar to the OM permeability, the change of IM permeability were also affected by the type and concentration of metal ions. But it did not mean that the higher of the concentration of metal ions, the greater the change of membrane permeability, nor the stronger of the adsorption capacity. In summary, the change of membrane permeability was the key factor for bacteria to adsorb heavy metals, but when degree of change exceeded its self-repair capacity, it became non-resistant or low-resistant.

\section{Analysis of changes in bioactive macromolecules}

The excessive release of macromolecules such as proteins (Pr), phospholipid (PL), alkaline phosphatase (ALP) will definitely affect the normal function of cells. Without a doubt, with the change of membrane permeability, macromolecules will release to the outside of the cells. In terms of proteins and phospholipid, the variation trend was consistent with the change of membrane permeability (Fig. 4囚5), which was also the reason that why cells hardly grow under the stress of $\mathrm{Pb}^{2+}$ and $\mathrm{Zn}^{2+}$. On the contrary, the release trend of alkaline phosphatase was consistent with the heavy metal adsorption capacity of 
strain $\mathrm{JC} 1$.We speculated that alkaline phosphatase participates in the hydrolysis reaction of microorganisms and generates phosphate ions (- $\left.\mathrm{PO}_{4}{ }^{3-}\right)$ and free hydroxyl groups $(-\mathrm{OH})$, then the $-\mathrm{PO}_{4}{ }^{3-}$ and $-\mathrm{OH}$ complexed with the positive metal ions such as $\mathrm{Cr}^{6+}$ and $\mathrm{Cu}^{2+}$, also with $\mathrm{Pb}^{2+}$ and $\mathrm{Zn}^{2+}$.

\section{Transport proteome of S. mizophila JC1}

In total, 323 transport proteins belonging to nine major transport protein classes were predicted in the genome of S. rhizophila JC1 (4.28 Mb) (Table S1). Most of them were primary active transporters (TC\#3), electrochemical potential-driven transporters (TC\#2) and channels/pores (TC\#1). They represented only $9 \%$ of the total number of predicted proteins. In addition, only $33 \% \varangle 50 \%$ of superior heavy metal-resistant bacteria which genome larger than $4 \mathrm{Mb}(\mathrm{Rozycki}$ and Nies 2009). The distribution of transport proteins was similar to these bacteria. Thus, the adsorption and resistance of $S$. rhizophila JC1 to heavy metals may be independent of the number of transporters, the types of transporter may be the key factor.

\section{Heavy-metal transport proteins}

Because cells do not contain the NADPH level required for reductase activities and there is a lack of methylation or other covalent modification mechanisms, some divalent metal ions cannot be discharged from cells independently. However, the three efflux systems (CDF, RND and P-type ATPases), containing almost all of the metal transport proteins, actively mediate the intracellular to extracellular excretion of divalent metal ions (Rozycki and Nies 2009). Therefore, the numbers and functions of transport proteins involved in the three efflux systems were analyzed in S. rhizophila JC1.

\section{The cation diffusion facilitator (CDF) system}

The CDF system members are chemiosmotic ion/proton exchangers that are involved in the efflux of divalent metal cations (Nies 2003) and the transport of metals from the cytoplasm across the cytoplasmic membrane into the periplasmic space (Higuchi et al. 2009) As shown in Table 1, two predicted proteins constituted the CDF system in S. rhizophila JC1. The CzCD/zitB (JC1_GM001116) was predicted as $\mathrm{Co}^{2+} / \mathrm{Zn}^{2+/} \mathrm{Cd} 2+$ efflux system protein that included cation efflux, cation transporter ATPase $\mathrm{C}$ terminal as well as zinc transporter dimerization domains. Furthermore, its homolog was confirmed to bind $\mathrm{Cu}^{2+}$ and $\mathrm{Ni}^{2+}$ in Ralstonia metallidurans (Anton et al. 2004). The other CDF system member (TC\#2.A.4.4.7) (JC1_GM001883) was predicted to be an integral membrane protein, which was confirmed as a lead $\left(\mathrm{Pb}^{2+}\right)$ efflux transporter (PbtF) in Achromobacter xylosoxidans (Hložková et al. 2013), and it may provide sites for the targeted utilization of proteins. The sequences of these two proteins were provided in Additional file 1.

\section{The resistance-nodulation-division (RND) efflux system}

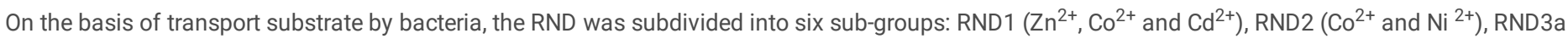
(divalent cations), RND3b (monovalent cations), RND4 ( $\left.\mathrm{Cu}^{+} / \mathrm{Ag}^{+}\right)$and RND5 ( $\left.{ }^{2+}\right)$ (Nies et al. 2003). Generally, these proteins are trimeric proteins that generate protein complexes named out membrane factor (OMF)(Koronakis et al. 2000) and a periplasmic adapter protein of membrane fusion protein(MFP)family(Akama et al. 2004).

Six heavy-metal efflux proteins were predicted in S. rhizophila JC1 (Table 1). Among them, two types of czcCBA operons (TC\#2.A.6.1.15 and TC\#2.A.6.1.16) form a complete cobalt-zinc-cadmium resistance system homologous to that in Escherichia coli (Tam et al. 2019). czcA is the RND protein, having at least one transmembrane domain and a membrane-spanning helical or beta-stranded domain that embeds in the membrane. czcC is a member of the OMP family that forms a trimeric channel and a long helical barrel that allows the export of a variety of substrates in Gram-negative bacteria. In S. rhizophila JC1, the czcCBA operon may transport $\mathrm{Cd}^{2+}$ and $\mathrm{Zn}^{2+}$, as well as $\mathrm{Co}^{2+}$, because there is a gene downstream of $\mathrm{czcA}$ that encodes a Cd ${ }^{2+} / \mathrm{Zn}^{2+}$-exporting ATPase $(\mathrm{Fig}$. $6)$.

No regulatory gene was predicted near the two types of $c z c C B A$ operon, which was in contrast to the $c n r$ in genome of $R$. metallidurans $\mathrm{CH} 34$ (cnrYXHCBA), czc in genome of $R$. metallidurans and Alcaligenes eutrophus (czcCBADRS/czcNICBADRS) and ncc in genome of Achromobacter xilosoxidans $31 \mathrm{~A}$ (nccYXHCBAN)(Grass et al. 2000, Grosse et al. 2004). The amino acid alignment showed these paralogs share very low overall identity levels, as follows (Figure 6): JC1_001887 and JC1_003695 (czcC, OMF), 23.37\% identity, JC1_001888 and JC1_003694 (czcB, MFP), 19.71\% identity, and JC1_001889 and JC1_003693 (RND protein), 47.45\% identity. Moreover, two additional genes (JC1_001886 and JC1_001890) were contained in the czc locus. JC1_001891, located downstream of the czcA gene, encodes the $\mathrm{Cd}^{2+} / \mathrm{Zn}^{2+}$-exporting ATPase $(\mathrm{ZntA})$ that provides energy for $\mathrm{Cd}^{2+}, \mathrm{Zn}^{2+}$ and $\mathrm{Co}^{2+}$ efflux through hydrolysis The low similarity level of these proteins suggested that they have bifurcated considerably in the process of evolution, they may have obtained unique way in protecting strain JC1 from being damaged by heavy metals (Valencia et al. 2013). The $\mathrm{Ni}^{2+} / \mathrm{Co}^{2+}$-uptake system was not predicted in the genome of strain $\mathrm{JC} 1$, but fortunately the $\mathrm{Mg}^{2+} / \mathrm{Co}^{2+}$-uptake system was predicted. It may be that $S$. rhizophila $\mathrm{JC1}$ decreased its $\mathrm{Ni}^{2+} / \mathrm{Co}^{2+}$-detoxification function, but to maintaining homeostasis through controlling the efflux of outer membrane (Rozycki and Nies 2009). This finding meant the stepwise evolutionary from the ancestor of S. rhizophila had already able to deal with heavy metals (Nies 2003, Rozycki and Nies 2009).

One possible $\mathrm{Cu}(\mathrm{I}) / \mathrm{Ag}(\mathrm{I})$-exporting RND4 protein (TC\#2.A.6.1.8) was predicted in S. rhizophila JC1. This protein, as part of the copper resistance operon cluster, was encoded by chromosomal DNA and induced by $\mathrm{Cu}^{2+}$ (Moraleda et al. 2010). According to Nies (2006) classification of HME-RND, no specific RND3a $\left(\mathrm{Zn}^{2+}\right)$ or RND3b $\left(\mathrm{Co}^{2+}\right)$ transporters were predicted in S. rhizophila JC1. We speculated that $\mathrm{Zn}^{2+}$ and $\mathrm{Co}^{2+}$ detoxification by strain $\mathrm{JC} 1$ may depend on the chelation of related anionic groups.

\section{P-type ATPase}

S.rhizophila JC1 contains a relatively low number (5) of predicted P-type ATPases (Table 1). After concerned, copA involved a polypeptide domain of approximately 50 amino acid residues with two cysteines. Owing to the presence of this domain that the copA may be related to the detoxification of $\mathrm{Cu}^{+} / \mathrm{Ag}^{+}$, 
but ineffective to divalent ions that in contrast to copB. However, in Bradyrhizobium liaoningense by Liang (2016), copA is responsible for resistance to Cu+, $\mathrm{Zn}^{2+}$ and $\mathrm{Cd}^{2+}$. Moreover, copA induced gold $\left(\mathrm{Au}^{2+}\right)$ detoxification due to a cytoplasmic metal-binding protein (Pontel et al. 2007).

The ZntA(JC1_GM001891) predicted in S. rhizophila JC1 was the P5-type ATPase, having plasma membrane C-terminal and N-terminal auto inhibitory domains. As described in Cupriavidus metallidurans, ZntA was the downstream gene of $c z c C B A$ operon that encoded the $\mathrm{Cd}^{2+} / \mathrm{Zn}^{2+}$-exporting ATPase, and its side chains, containing Met254, Cys476 and His807 contributed to $\mathrm{Cd}^{2+}, \mathrm{Co}^{2+}$ and $\mathrm{Zn}^{2+}$ binding and transporting, respectively(Smith et al. 2017).

\section{Mercury detoxification}

Three mercury detoxification proteins, MerP/T/R (JC1_GM001926-JC1_GM001928), were predicted in S. rhizophila JC1. MerP contributed to binding the highly toxic $\mathrm{Hg}^{2+}$, MerT was responsible for importing $\mathrm{Hg}^{2+}$ into cytoplasm, MerR was the regulator of meroperon (Silver and Phung 1996). Unlike in $C$. metallidurans $\mathrm{CH} 34$ (Rozycki and Nies 2009), there were no MerA and merRPT fragments predicted in S. rhizophila JC1. However, two copper efflux regulators (JC1_GM002046 and JC1_GM002150) and a redox-sensitive transcriptional activator SoxR (JC1_GM000920) were predicted.

In summary, the efflux system of S. rhizophila JC1 contained the same types of metal transport proteins as many other metal-resistant bacteria. Its low number of transport proteins may be the result of evolution.

\section{Comparative genomics analysis}

\section{Molecular evolutionary analysis}

A molecular evolutionary analysis is an valuable measure to evaluate similarities or differences, and to match functional gene information, between model organisms and uncharacterized newly sequenced genomes(Gabaldón and Koonin 2013).

The evolutionary relationships of the 15 investigated bacteria were shown in Fig. S1. S.rhizophila JC1 had long-distance evolutionary relationships with other strains, which indicated that there may be great differences in gene expression levels. In addition, the lower number of transporters in genome of $S$. rhizophila JC1 compared with the other strains was the result of evolution.

\section{Numbers of paralogs and transporters in the compared bacteria}

For more information about the origin of metal-resistance gene of $S$. rhizophila JC1, the paralogs of predictive gene products of 15 investigated bacteria were analyzed by BLAST comparisons. On the whole, the frequency level of paralogs among compared bacteria was approximately $8 \%$ (Table 2 ). The relatively closest relationship with Salmonella enterica P-stx-12, has 30\% paralogs, indicating that most of its increased genome size may be due to gene replication events during the bacterial species formation process.

In terms of most investigated strains, the frequency of paralogs of transporters was close to the $7 \%$ (Table 2). High percentages of paralogous proteinencoding genes were located on plasmids in S. rhizophila JC1 (28\%), unlike the plasmid in Enterococcus hirae NCTC12204 (5\%). When only considered the plasmid encoding paralogs of transporters, $29 \%$ of the S. rhizophila JC1 proteins represented paralogs. Therefore, duplicating genes encoding transport proteins, relocating them to plasmids and altering the substrate range and their products' expression patterns may have been important evolutionary processes in the evolution of S. rhizophila JC1.

\section{Comparison of transition-metal transporters}

A higher number of heavy metal-specific transport proteins were predicted of strain JC1 through comparing with 15 investigated strains, especially proteins belonging to three efflux system (Table 3). For instance, the number of P-Type ATPases that contribute to $\mathrm{Cd}^{2+} / \mathrm{Zn}^{2+} \mathrm{even}$ to $\mathrm{Cu}^{+} / \mathrm{Cu}^{2+} \mathrm{was}$ nearly twice of other compared strains. Regrettably, the number of zinc transporters and mercuric transporters were relatively lower. The $\mathrm{Mg}^{2+} / \mathrm{Co}^{2+}$-transport protein (TC\#9.A.40.1.2, JC1_GM001315) that belong to the HlyC/CorC family was predicted in S. rhizophila JC1. We speculated that it may have great detoxification ability to divalent cations due to its approximately 440 amino acids with an N-terminal four TMS domain. Here, we further speculated that the metal resistance gene of S. rhizophila JC1 appeared to have evolved by horizontal acquisition or duplication (Rozycki and Nies 2009). The detoxification ability to heavy metal was perfect, even though the number of detoxification system had decreased.

\section{Validation of predicted genes by qPCR}

The expression level of 4 genes that respectively represents three efflux systems were identified by qPCR. Each gene to be validated was successfully amplified and produced a single band. $C Z C D, C Z c B$ and $Z n t A$ were up regulated after treated with $\mathrm{Cr}^{6+}, \mathrm{Pb}^{2+}$ and $\mathrm{Zn}^{2+}$ as compared to the $\mathrm{CK}^{2} \mathrm{Cu}^{2+}$-exporting ATPase and $Z n t A$ were up regulated in after treated with $\mathrm{Cu}^{2+}$ as compared to the $\mathrm{CK}$. Among them, $C z c \mathrm{D}, c z c B$ and $Z n t A$ exhibited higher expression levels in S. rhizophila JC1 treated with $\mathrm{Cr}^{6+}$ compared to samples treated with $\mathrm{Pb}^{2+}$ and $\mathrm{Zn}^{2+}$. The expression level of each gene used for identification showed significantly difference by P-value evaluation. The expression trend of 4 selected genes was consistent with the metal ions-removal efficiency and predicted results, which further confirmed that transport proteins play important roles in process of heavy metal adsorption.

\section{Conclusion}

The S. rhizophila JC1 showed great adsorption capacity for heavy metals, especially for $\mathrm{Cu}^{2+}$ and $\mathrm{Cr}^{6+}$. The moderate change of membrane permeability and replacement of essential element sites may be the key factors for the adsorption of heavy metals by bacteria, and the exopolysaccharides (EPS) is the main 
means of heavy metals adsorption by bacteria. In addition, transport proteins play the important roles in the adsorption and detoxification of heavy metals. We hope that our research can provide relevant genetic resources for heavy metal detoxification, and then make a certain contribution to the remediation of heavy metal contaminated soil.

\section{Declarations}

Authors' contributions Design: Jixiang Chen, Yonggang Wang, Performance: Shangchen Sun, Kexin Zhang, Yamiao Wu, Data analysis: Shangchen Sun, Yonggang Wang, Feifan Leng, Writing-original draft preparation:Shangchen Sun, Kexin Zhang, Writing-review and editing: Jixiang Chen, Feifan Leng, Funding acquisition: Jixiang Chen, Yonggang Wang. All authors read and approved the final manuscript.

Funding This work was supported by the National Natural Science Foundation of China (No. 31760028), Petrochina Beijing Gas Pipeline Co Ltd. Scientific research project (2014D-4610-0501).

Data availability The datasets used and/or analyzed during the current study are available from the corresponding author on reasonable request.

\section{Compliance with ethical standards}

Conflict of interest The authors declare that they have no conflict of interest.

Ethical approval Not applicable.

Consent to participate Not applicable.

Consent for publication Not applicable.

\section{References}

1. Akama H, Matsuura T, Kashiwagi S, Yoneyama H, Narita SI, Tsukihara T (2004) Crystal structure of the membrane fusion protein, MexA, of the multidrug transporter in Pseudomonas aeruginosa. J Biol Chem 279 (25): 25939-25942. https://doi.org/10.1074/JBC.C400164200

2. Anton A, Weltrowski A, Haney CJ, Franke S, Grass G, Rensing C, Nies DH (2004) Characteristics of zinc transport by two bacterial cation diffusion facilitators from Ralstonia metallidurans $\mathrm{CH} 34$ and Escherichia coli. J Bacteriol 186 (22): 7499-7507. https://doi.org/10.1128/JB.186.22.7499-7507.2004

3. Arguello JM, Manuel GG, Raimunda D (2011) Bacterial transition metal P1B-ATPases: transport mechanism and roles in virulence. Biochemistry 50 (46): 9940-9949. https://doi.org/10.1016/B978-0-12-307212-2.50008-9

4. Barber ZS, Uebe R, Davidov GY, Navon D, Sherf JH, Chill KI, Bitton R, Zarivach R (2016) Disease-Homologous Mutation in the Cation Diffusion Facilitator Protein MamM Causes Single-Domain Structural Loss and Signifies Its Importance. Nature 6: 31933. https://doi.org/10.1038/srep31933

5. Cui D, Tan C, Deng HN, Gu XX, Pi SS, Chen T, Zhou L, Li (2020) Biosorption Mechanism of Aqueous $\mathrm{Pb}^{2+}$, Cd ${ }^{2+}$, and $\mathrm{Ni}^{2+}$ Ions on Extracellular Polymeric Substances (EPS). Archaea 2020: 1-9. https://doi.org/10.1155/2020/8891543

6. Gabaldón T, Koonin EV (2013) Functional and evolutionary implications of gene orthology. Nat Rev Genet 14 (5): $360-366$. https://doi.org/10.1038/nrg3456

7. Grass G, Grosse C, Nies DH (2000) Regulation of the cnr cobalt and nickel resistance determinant from Ralstonia sp. strain CH34. J Bacteriol 182 (5): 1390-1398. https://doi.org/10.1128/JB.182.5.1390-1398.2000

8. Higuchi T, Hattori M, Tanaka Y, Ishitani R, Nureki O (2009) Crystal structure of the cytosolic domain of the cation diffusion facilitator family protein. Proteins 76 (3): 768-771. https://doi.org/10.1002/prot.22444

9. Hiraizumi M, Yamashita K, Nishizawa T, Nureki O (2019) Cryo-EM structures capture the transport cycle of the P4-ATPase flippase. Science 365: 11491155. https://doi.org/10.1101/666321

10. Hložková K, Suman J, Strnad H, Ruml T, Paces V, Kotrba P (2013) Characterization of pbt genes conferring increased $\mathrm{Pb}^{2+}$ and $\mathrm{Cd}^{2+}$ tolerance upon Achromobacter xylosoxidans A8. Res Microbiol 164 (10): 1009-1018. https://doi.org/10.1016/j.resmic.2013.10.002

11. Kambe T (2012) Molecular architecture and function of ZnT transporters. Curr Top Membr 69: 199-220. https://doi.org/10.1016/B978-0-12-3943903.00008-2

12. Kang CH (2016) Heavy metal and antibiotic resistance of ureolytic bacteria and their immobilization of heavy metals. Ecol Eng $97: 304-312$. https://doi.org/10.1016/j.ecoleng.2016.10.016

13. Kim EH, Nies DH, McEvoy MM, Rensing C (2011) Switch or funnel: how RND-type transport systems control periplasmic metal homeostasis. J Bacteriol 10 (193): 2381-2387. https://doi.org/10.1128/JB.01323-10

14. Koronakis V, Sharff A, Koronakis E, Luisi B, Hughes C (2000) Crystal structure of the bacterial membrane protein TolC central to multidrug efflux and protein export. Nature 405 (6789): 914-919. https://doi.org/10.1038/35016007

15. Liang JQ, Zhang MZ, Lu MM, Li ZF, Shen XH, Chou MX, Wei GH (2016) Functional characterization of a csoR-cueA divergon in Bradyrhizobium liaoningense CCNWSX0360, involved in copper, zinc and cadmium cotolerance. SCI REP-UK 6: 35155. https://doi.org/10.1038/srep3515

16. Liu H, Du Y, Wang X, Sun L (2004) Chitosan kills bacteria through cell membrane damage, Int. J. Food Microbiol 95 (2): $147-155$. https://doi.org/10.1016/j.ijfoodmicro.2004.01.022 
17. Loh B, Grant C, Hancock RE (1984) Use of the fluorescent Probe 1-N-phenylnaphthylamine to study the interactions of aminoglycoside antibiotics with the outer membrane of Pseudomonas aeruginosa, Antimicrob. Agents Chemother 26 (4): 546-551. https://doi.org/10.1128/AAC.26.4.546

18. Ma Z, Jacobsen FE, Giedroc DP (2009) Metal Transporters and Metal Sensors: How Coordination Chemistry Controls Bacterial Metal Homeostasis. Chen Rev 109 (10): 4644-4681. https://doi.org/10.1021/cr900077w

19. Maseda H, Kitao M, Shima E, Yoshihara E, Nakae T (2002) A novel assembly process of the multicomponent xenobiotic efflux pump in Pseudomonas aeruginosa. Mol Microbiol 3 (46): 677-686. https://doi.org/10.1046/j.1365-2958.2002.03197.x

20. Meng D, Bruschweiler LL, Zhang F, Brüschweiler R (2015) Modulation and Functional Role of the Orientations of the N- and P-Domains of Cu+ Transporting ATPase along the lon Transport Cycle. Biochemistry 54: 5095-5102. https://doi.org/10.1021/acs.biochem.5b00420

21. Moraleda MA, Pérez J, Extremera AL, Dorado JM (2010) Differential regulation of six heavy metal efflux systems in the response of Myxococcus xanthus to copper. Appl Biochem and Biotech 76 (18): 6069-6076. https://doi.org/10.1128/AEM.00753-10

22. Mohite BV, Koli SH, Patil SV (2018) Heavy Metal Stress and Its Consequences on Exopolysaccharide (EPS)-Producing Pantoea agglomeran. Appl Biochem and Biotech 186(1):199-216. https://doi.org/10.1007/s12010-018-2727-1

23. Nagakubo S, Nishino K, Hirata T, Yamaguchi A (2002) The putative response regulator BaeR stimulates multidrug resistance of Escherichia coli via a novel multidrug exporter system, MdtABC. J Bacteriol 15 (184): 4161-4167. https://doi.org/10.1128/JB.184.15.4161-4167.2002

24. Nies DH (2003) Efflux-mediated heavy metal resistance in prokaryotes. FEMS microbiol rev 27 (2): 313-339. https://doi.org/10.1016/S0168$6445 \% 2803 \% 2900048-2$

25. Nies DH, Rehbein G, Hoffmann T, Baumann C, Grosse C (2006) Paralogs of genes encoding metal resistance proteins in Cupriavidus metallidurans strain CH34. J Mol Microb Biotech 11 (1-2): 82-93. https://doi.org/10.1159/000092820

26. Novinscak A, Filion M (2011) Effect of soil clay content on RNA isolation and on detection and quantification of bacterial gene transcripts in soil by quantitative reverse transcription-PCR. Appl Environ Microb 77, 6249-6252. https://doi.org/10.1128/AEM.00055-11

27. Panja S, Aich P, Jana B, Basu T (2008) How does plasmid DNA penetrate cell membranes in artificial transformation process of Escherichia coli? Mol. Membr. Biol 25 (5): 411-422. https://doi.org/10.1016/S0140-6736(00)04817-0

28. Paulsen IT, Saier MH (1997) A novel family of ubiquitous heavy metal ion transport proteins. J membrane Boil 156: 99-103. https://doi.org/10.1007/s002329900192

29. Pontel LB, Audero ME, Espariz M, Checa SK, Soncini, FC (2010) GolS controls the response to gold by the hierarchical induction of Salmonella-specific genes that include a CBA efflux-coding operon. Mol oral Microbiol 66 (3): 814-825. https://doi.org/10.1111/j.1365-2958.2007.05963.x

30. Rozycki TV, Nies DH (2009) Cupriavidus metallidurans: evolution of a metal-resistant bacterium. Antonie van Leeuwenhoek 96 (2): $115-139$. https://doi.org/10.1007/s10482-008-9284-5

31. Rusinova-Videva S, Nachkova S, Adamov A, et al.(2020) Antarctic yeast. J Chem Technol Biot https://doi.org/10.1002/jutb.6321.

32. Saier MH, Tam R, Rerzer A (2010) Two novel families of bacterial membrane proteins concerned with nodulation, cell division and transport. Mol Microbiol 11 (5): 841-847. https://doi.org/10.1111/j.1365-2958.1994.tb00362.x

33. Schlesinger MJ, Levinthal C (1989) in: Molecular Biology, Elsevier, pp 210-222.

34. Silver S, Phung LT (1996) Bacterial heavy metal resistance: new surprises. Annual Review of Microbiology 50: $753-789$. https://doi.org/10.1021/acs.biochem.6b01022

35. Smith AT, Ross MO, Hoffman BM, Rosenzweig AC (2017) Metal Selectivity of a Cd-, Co-, and Zn-Transporting P1B-type ATPase. Biochemistry 56 (1): 8595. https://doi.org/10.1016/j.jmb.2019.12.025

36. Tam HK, Malviya VN, Foong WE, Herrmann A, Malloci G, Ruggerone P, Vargiu AV, Pos KM (2019) Binding and transport of carboxylated drugs by the multidrug transporter AcrB. J Mol Biol 432 (4): 861-877. https://doi.org/10.1186/1471-2180-13-79

37. Valencia EY, Braz VS, Guzzo C, Marques MV (2013) Two RND proteins involved in heavy metal efflux in Caulobacter crescentus belong to separate clusters within proteobacteria. Bmc Microbiol 13 (1): 79-79. https://doi.org/10.1016/j.jconrel.2006.09.071

38. Wamel AV, Kooiman K, Emmer M, et al (2006) Ultrasound microbubble induced endothelial cell permeability. J Control Release 116 (2): e100-e102. https://doi.org/10.1074/JBC.M103598200

39. Wang JP, Li GY, Yin HL, An TC (2020) Bacterial response mechanism during biofilm growth on different metal material substrates: EPS characteristics, oxidative stress and molecular regulatory network analysis. Environ Res https://doi.org/10.1016/j.envres.2020.109451.

40. Wang QF, Li Q, Lin Y, Hou Y, et al (2020) Biochemical and genetic basis of cadmium biosorption by Enterobacter ludwigii LY6, isolated from industrial contaminated soil. Environ Pollut https://doi.org/10.1016/j.envpol.2020.114637

41. Waschuk SA, Elton EA, Darabie AA, Fraser PE, McLaurin JA (2001) Cellular membrane composition defines A beta-lipid interactions, J. Biol. Chem 276: 33561-33568. https://doi.org/10.1002/mbo3.182

42. Wang YG, Sun SC, et al (2021) Optimization and mechanism exploration for Escherichia coli transformed with plasmid pUC19 by the combination with ultrasound treatment and chemical method. Ultrason Sonochem https://doi.org/10.1016/j.ultsonch.2021.105552

43. Yang L, Lu S, Belardinelli J, Claustre EH, Jones V, Jackson M, Zgurskaya HI (2014) RND transporters protect Corynebacterium glutamicum from antibiotics by assembling the outer membrane. Microbiologyopen 3 (4): 484-496.https://doi.org/10.1016/j.carbpol.2013.09.021

44. Ye SH, Zhang MP, Yang H, et al (2014) Biosorption of $\mathrm{Cu}^{2+}, \mathrm{Pb}^{2+}$ and $\mathrm{Cr}^{6+}$ by a novel exopolysaccharide from Arthrobacter ps-5. Carbohyd Polym 101:5056. https://doi.org/10.1016/j.carbpol.2013.09.021 
45. Zhang ZL, Cai RH, Zhang WH, Fu YN, Jiao NZ (2017) A Novel Exopolysaccharide with Metal Adsorption Capacity Produced by a Marine Bacterium Alteromonas sp. JL2810. Mar drugs https://doi.org/10.3390/md15

\section{Tables}

Table 1 Heavy metal-specific transport proteins in S. rhizophila JC1

\begin{tabular}{|lllll|}
\hline Predicted protein & Transporter & TC number & TMSs \\
\hline CDF proteins & & & \\
sIm:BIZ42_15070 & czcD, zitB & 2.A.4.1.1 & 6 \\
\hline stek:AXG53_19310 & & 2.A.4.4.7 & 6 \\
\hline RND proteins & & & \\
\hline stek:AXG53_08210 & czcA & 2.A.6.1.15 & 12 \\
\hline stek:AXG53_19335 & czcC & & 0 \\
\hline psd:DSC_03900 & czcB & & 0 \\
\hline sIm:BIZ42_09005 & czcA & 2.A.6.1.16 & 12 \\
\hline srh:BAY15_0023 & czcB & & 0 \\
\hline sIm:BIZ42_09015 & czcC & & 1 \\
\hline sdf:ACG33_13555 & cusA, silA & 2.A.6.1.8 & 12 \\
\hline slm:BIZ42_11620 & TC.CPA1 & 2.A.36.3.1 & 13 \\
\hline smt:Smal_3140 & TC.KEF & 2.A.37.1.5 & 13 \\
\hline xpe:BJD13_00190 & pcoB,copB & 1.B.76.1.1 & 1 \\
\hline P-type ATPase & & & 8 \\
\hline stek:AXG53_08205 & zntA & 3.A.3.6.27 & 5 \\
\hline xga:BI317_24540 & copA, & 3.A.3.5.39 & 8 \\
\hline stek:AXG53_00105 & copB & 3.A.3.5.15 & 8 \\
\hline sdf:ACG33_13605 & copB & 3.A.3.5.38 & 8 \\
\hline spe:Spro_2413 & copA, & 3.A.3.5.20 & 8 \\
\hline Mer proteins & & & \\
\hline sdf:ACG33_13625 & merT & 1.A.72.3.1 & 3 \\
\hline
\end{tabular}

Table 2 Numbers of paralogs of proteins and transport proteins in the compared bacteria 


\begin{tabular}{|c|c|c|c|c|c|}
\hline \multirow[t]{2}{*}{ Bacterial strain } & \multirow[t]{2}{*}{ Replicons } & \multicolumn{2}{|l|}{ All proteins } & \multicolumn{2}{|c|}{ Transport proteins } \\
\hline & & Total number & Paralogs (\%) & Total number & Paralogs (\%) \\
\hline \multirow[t]{2}{*}{ S. rhizophila JC1 } & All & 3717 & $448(12 \%)$ & 323 & $32(10 \%)$ \\
\hline & plasmids & 276 & 77 (28\%) & 21 & $6(29 \%)$ \\
\hline \multirow[t]{2}{*}{ A.xylosoxidansMN001 } & All & 5227 & $418(8 \%)$ & 665 & $53(8 \%)$ \\
\hline & plasmids & 1023 & $153(15 \%)$ & 26 & $4(15 \%)$ \\
\hline \multirow[t]{2}{*}{ A.endophyticus AER10 } & All & 6187 & $557(9 \%)$ & 983 & $108(11 \%)$ \\
\hline & plasmids & 485 & $63(13 \%)$ & 34 & $5(15 \%)$ \\
\hline \multirow[t]{2}{*}{ A. eutrophus $\mathrm{H} 16$} & All & 6573 & $564(8 \%)$ & 1053 & $84(8 \%)$ \\
\hline & plasmids & 416 & $130(31 \%)$ & 45 & $13(28 \%)$ \\
\hline \multirow[t]{2}{*}{ B. subtilis 168} & All & 6367 & $446(7 \%)$ & 1018 & $92(9 \%)$ \\
\hline & plasmids & 638 & $128(20 \%)$ & 40 & $12(30 \%)$ \\
\hline \multirow[t]{2}{*}{ C. albicans } & All & 5428 & $271(5 \%)$ & 784 & $63(8 \%)$ \\
\hline & plasmids & 386 & 97 (25\%) & 36 & $11(31 \%)$ \\
\hline \multirow[t]{2}{*}{ C.metallidurans $\mathrm{CH} 34$} & All & 6351 & $643(10 \%)$ & 1002 & $93(9 \%)$ \\
\hline & plasmids & 416 & $141(34 \%)$ & 40 & $22(52 \%)$ \\
\hline \multirow[t]{2}{*}{ E. hiraeNCTC12204 } & All & 2574 & $201(8 \%)$ & 209 & $21(10 \%)$ \\
\hline & plasmids & 87 & $35(4 \%)$ & 8 & 0 \\
\hline \multirow[t]{2}{*}{ M. xanthus NBRC 13542} & All & 5983 & $658(11 \%)$ & 957 & $77(8 \%)$ \\
\hline & plasmids & 1026 & $308(30 \%)$ & 36 & $10(28 \%)$ \\
\hline \multirow[t]{2}{*}{ P. putida DSM3601 } & All & 4419 & $663(15 \%)$ & 718 & $43(6 \%)$ \\
\hline & plasmids & 379 & $68(18 \%)$ & 28 & $51(18 \%)$ \\
\hline \multirow[t]{2}{*}{ P. stutzeri DSM4166 } & All & 4212 & 787 (19\%) & 802 & $72(9 \%)$ \\
\hline & plasmids & 722 & $101(14 \%)$ & 26 & $3(12 \%)$ \\
\hline \multirow[t]{2}{*}{ S. entericaP-stx-12 } & All & 4690 & $1407(30 \%)$ & 962 & $88(9 \%)$ \\
\hline & plasmids & 998 & $250(25 \%)$ & 31 & $4(13 \%)$ \\
\hline \multirow[t]{2}{*}{ S. maltophilia D457R } & All & 5626 & $563(10 \%)$ & 839 & $92(11 \%)$ \\
\hline & plasmids & 1124 & $135(12 \%)$ & 28 & $5(18 \%)$ \\
\hline \multirow[t]{2}{*}{ S.pneumoniaeMGAS315 } & All & 2029 & $162(8 \%)$ & 243 & $19(8 \%)$ \\
\hline & plasmids & 89 & $8(9 \%)$ & 5 & 0 \\
\hline
\end{tabular}

${ }^{a}$ All the predicted proteins from respective bacteria were compared using BLASTP-based searches.

Table 3 Heavy metal-specific transport proteins in fifteen bacteria 


\begin{tabular}{|c|c|c|c|c|c|c|c|c|c|}
\hline \multirow{3}{*}{$\begin{array}{l}\text { TC } \\
\text { number }\end{array}$} & \multirow{3}{*}{$\begin{array}{l}\text { TC } \\
\text { family }\end{array}$} & \multicolumn{2}{|c|}{ S. rhizophila JC1 } & \multicolumn{6}{|l|}{ Orthologs ${ }^{c}$} \\
\hline & & $\mathrm{Abs}^{\mathrm{a}}$ & Paral $^{b}$ & A.xylosoxidans MN001 & A.endophyticus AER10 & $\begin{array}{l}\text { A.eutrophus } \\
\text { H16 }\end{array}$ & $\begin{array}{l}\text { B.subtilis } \\
168\end{array}$ & C.albicans & C.mei \\
\hline & & $\#$ & $\#$ & & & & & & \\
\hline 2.A. 6 & $\begin{array}{l}\text { HME- } \\
\text { RND }^{d}\end{array}$ & 18 & 3 & 3 & 2 & 3 & 6 & 3 & 2 \\
\hline 8.A.1 & MFP & 12 & 2 & 5 & 4 & 2 & 5 & 4 & 3 \\
\hline 1.B.7 & OMF & 9 & 2 & 7 & 4 & 5 & 2 & 1 & 2 \\
\hline 3.A.3 & $\begin{array}{l}\text { P-Type } \\
\text { ATPase }\end{array}$ & 13 & 5 & 6 & 6 & 8 & 6 & 7 & 5 \\
\hline 2.A.4 & CDF & 2 & 2 & 2 & 2 & 2 & 1 & 2 & 0 \\
\hline 9.A.2 & MerT & 1 & 1 & 1 & 1 & 0 & 0 & 0 & 2 \\
\hline 2.A.5 & ZUP & 2 & 0 & 0 & 0 & 0 & 0 & 0 & 0 \\
\hline 9.A.40 & MgCoT & 1 & 0 & 0 & 0 & 0 & 0 & 0 & 0 \\
\hline \multirow{3}{*}{$\begin{array}{l}\text { TC } \\
\text { number }\end{array}$} & \multirow{3}{*}{$\begin{array}{l}\text { TC } \\
\text { family }\end{array}$} & \multicolumn{7}{|l|}{ Orthologs } & \\
\hline & & P.putida & Pstutzeri & S.enterica & S.maltophilia & S.pneumoniae & M. xanthus & \multirow{2}{*}{$\begin{array}{c}\text { 5. hire } \\
\text { NCTC2204 }\end{array}$} & \\
\hline & & DSM3601 & DSM4166 & P-stx-12 & D457R & CP2215 & NBRC13542 & & \\
\hline 2.A.6.1 & $\begin{array}{l}\text { HME- } \\
\text { RND }\end{array}$ & 5 & 5 & 4 & 1 & 2 & 2 & 1 & \\
\hline 8.A.1 & MFP & 6 & 5 & 2 & 4 & 3 & 4 & 3 & \\
\hline 1.B.7 & OMF & 4 & 3 & 1 & 5 & 2 & 3 & 1 & \\
\hline \multirow[t]{2}{*}{ 3.A.3 } & P-Type & 4 & 8 & 5 & 6 & 8 & 7 & 7 & \\
\hline & ATPase & & & & & & & & \\
\hline 2.A.4 & $\mathrm{CDF}$ & 1 & 2 & 2 & 1 & 3 & 2 & 1 & \\
\hline 9.A.2 & MerT & 0 & 1 & 0 & 0 & 0 & 0 & 0 & \\
\hline 2.A.5 & ZuP & 0 & 0 & 0 & 0 & 0 & 0 & 0 & \\
\hline 9.A.40 & MgCoT & 0 & 0 & 0 & 0 & 0 & 0 & 0 & \\
\hline
\end{tabular}

aThe absolute number.

${ }^{\mathrm{b}}$ The number of proteins that are paralogs to proteins in strain JC1.

${ }^{\mathrm{c} O r t h o l o g s}$ in the indicated bacterial strains.

${ }^{\mathrm{d} H e a v y-m e t a l}$ efflux proteins of the RND superfamily. Names and TC classifications from http://www.tcdb.org/.

\section{Figures}



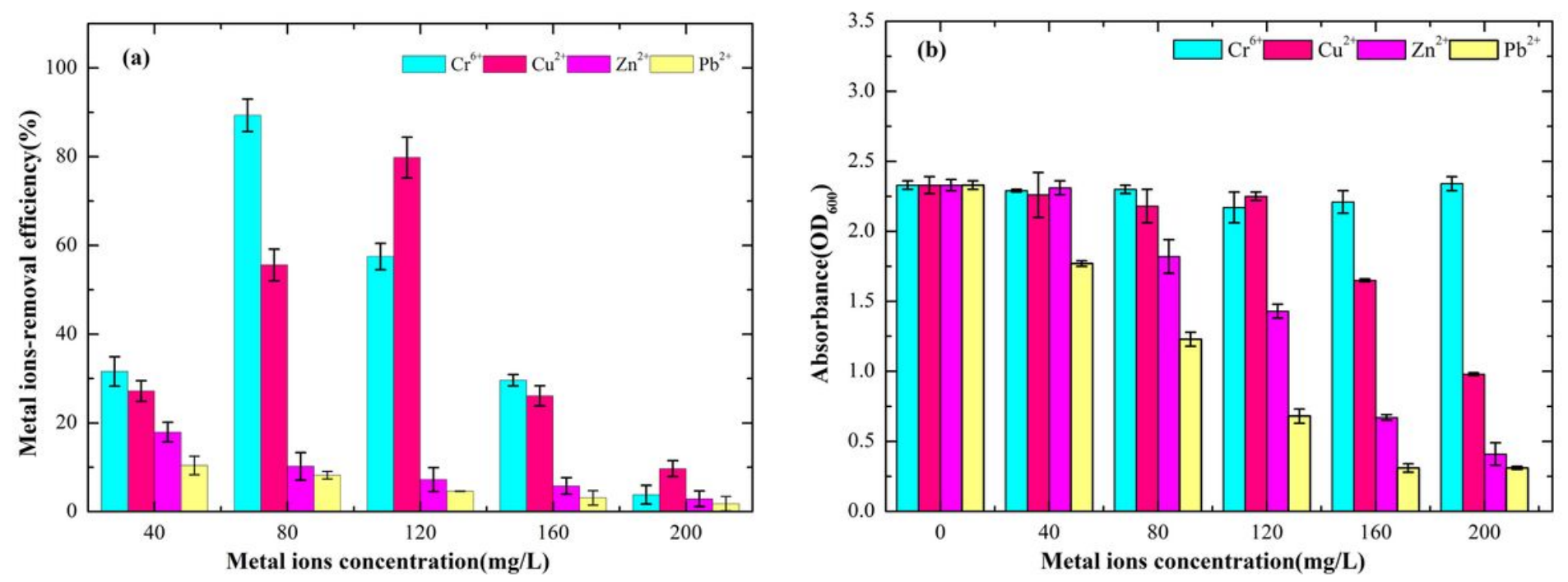

Figure 1

The toleration and adsorption to different metal ions of strain JC1 showed great difference. For instance, during S. rhizophila JC1 was respectively cultured in $\mathrm{LB}+\mathrm{Cu} 2+, \mathrm{LB}+\mathrm{Cr} 6+, \mathrm{LB}+\mathrm{Zn} 2+$ that the concentration of metal ions was $40 \sim 120 \mathrm{mg} / \mathrm{L}, 40 \sim 200 \mathrm{mg} / \mathrm{L}, 40 \mathrm{mg} / \mathrm{L}$ for 24 hours, there were no significant difference in OD600 value. However, during the concentration of $\mathrm{Zn} 2+$ and $\mathrm{Pb} 2+$ were increased to $160 \mathrm{mg} / \mathrm{L}$, the strain JC1 hardly grew. The adsorption efficiency was $79.8 \%$ when the concentration of Cu2+ was $120 \mathrm{mg} / \mathrm{L}-1$, while it reduced to $26.1 \%$ when the concentration reached to $160 \mathrm{mg} / \mathrm{L}$. More interesting was that with the concentration was $40 \sim 200 \mathrm{mg} \cdot \mathrm{L}-1$ of $\mathrm{Cr} 6+$, there had no significant suppression on the growth of bacteria, but only showed maximum adsorption efficiency of $89.3 \%$ when the concentration was $80 \mathrm{mg} / \mathrm{L}$. In terms of Pb2+ and Zn2+, the strain JC1 hardly showed adsorption ability

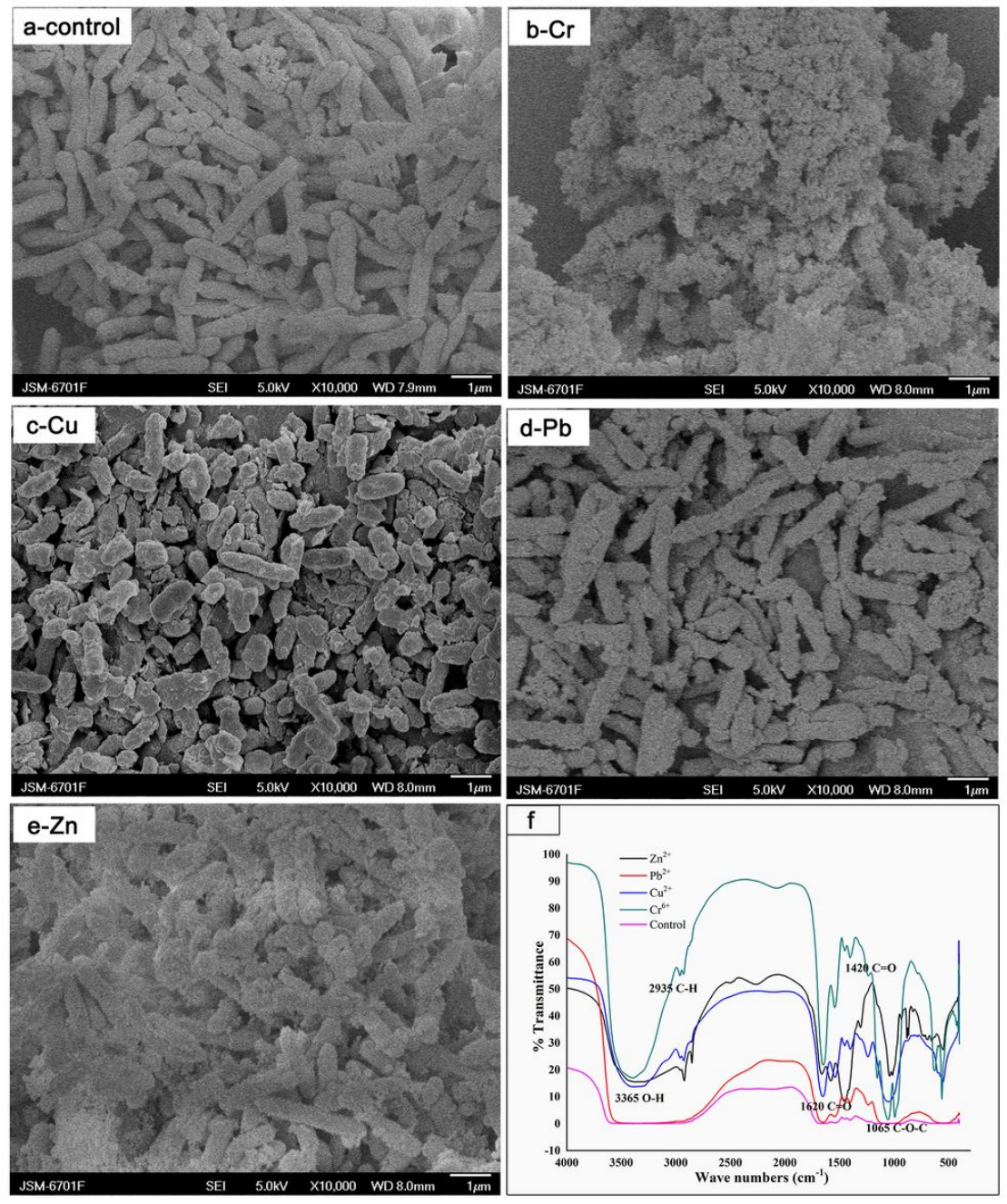


Figure 2

The morphological feature of strain JC1 comparison between metal ions stressed-cells and unstressed-cells was performed with SEM analysis. In different metal ions stress condition, different cell morphology was observed
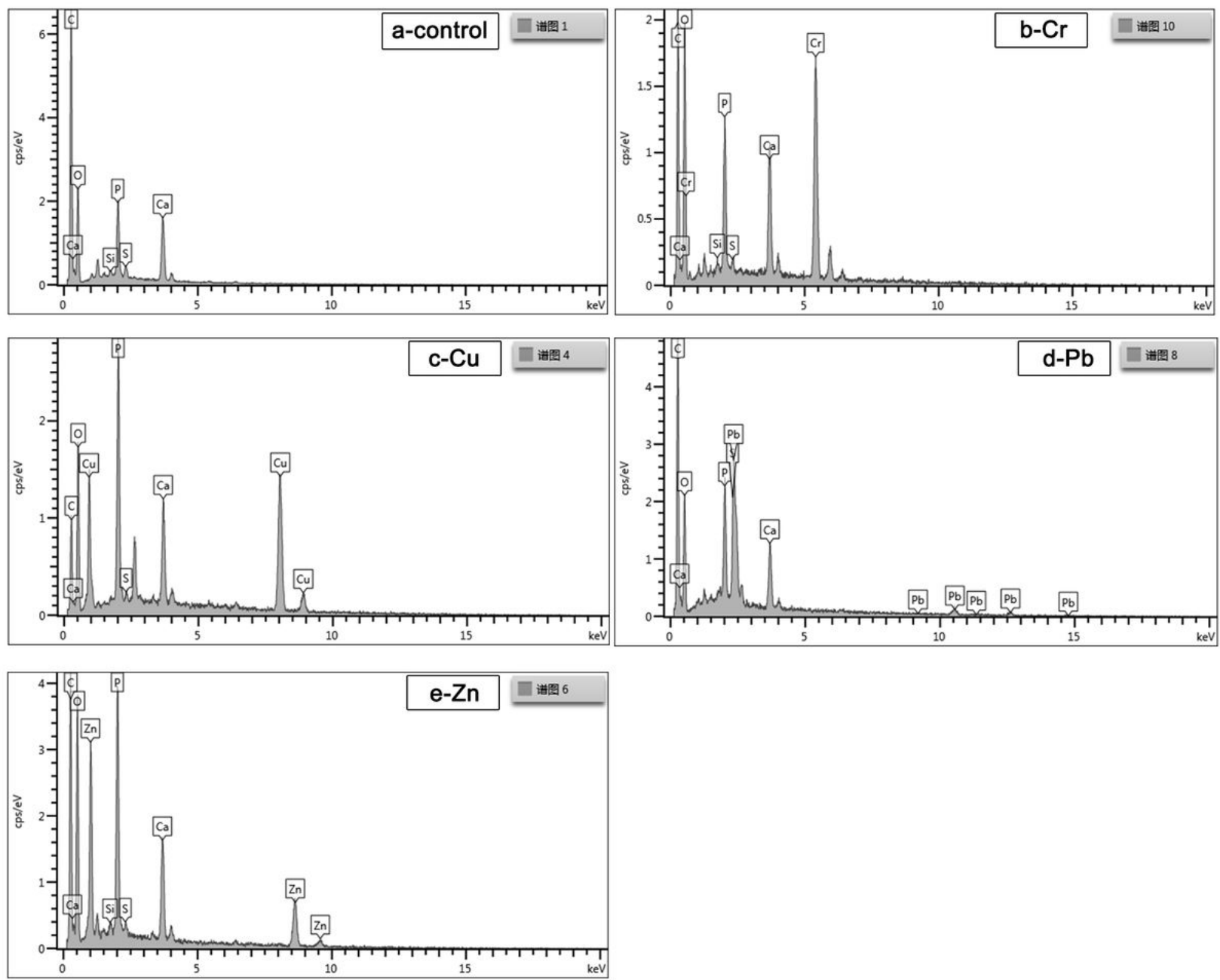

Figure 3

Generally, non-metallic elements such $0, \mathrm{C}$, Si and non-toxic metal elements such as Ca2+, Fe2+/Fe3+ were the basic elements to maintain normal growth and metabolism of microorganism. However, some toxic metals such as $\mathrm{Cr} 6+$ or $\mathrm{Pb} 2+$ will exist in the cells through sites replacement due to atomic radius, cell structure. The result of element composition analysis after metal ions stress was shown in Fig. 3. 


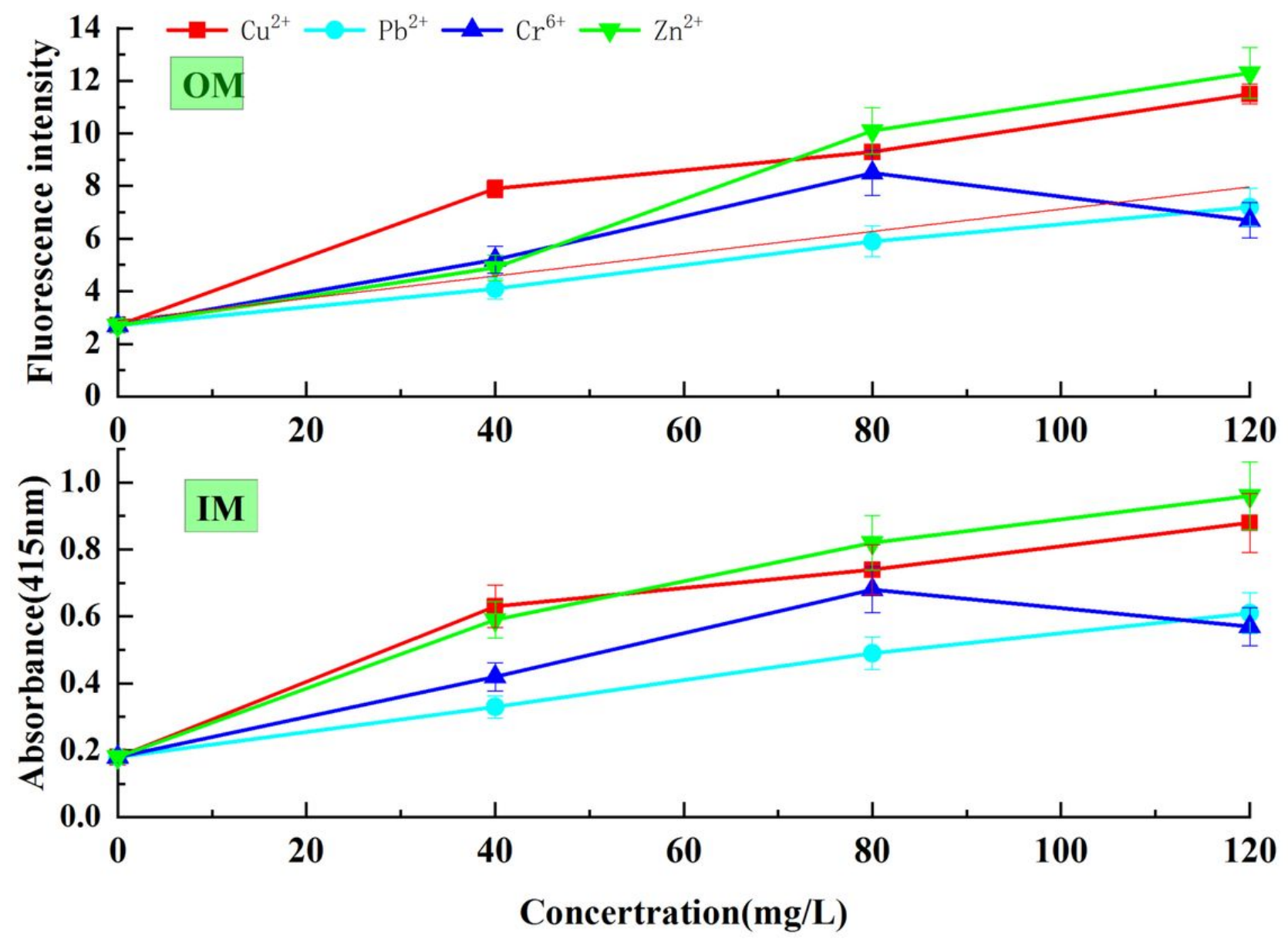

Figure 4

The change of OM permeability under different heavy metal stress. 


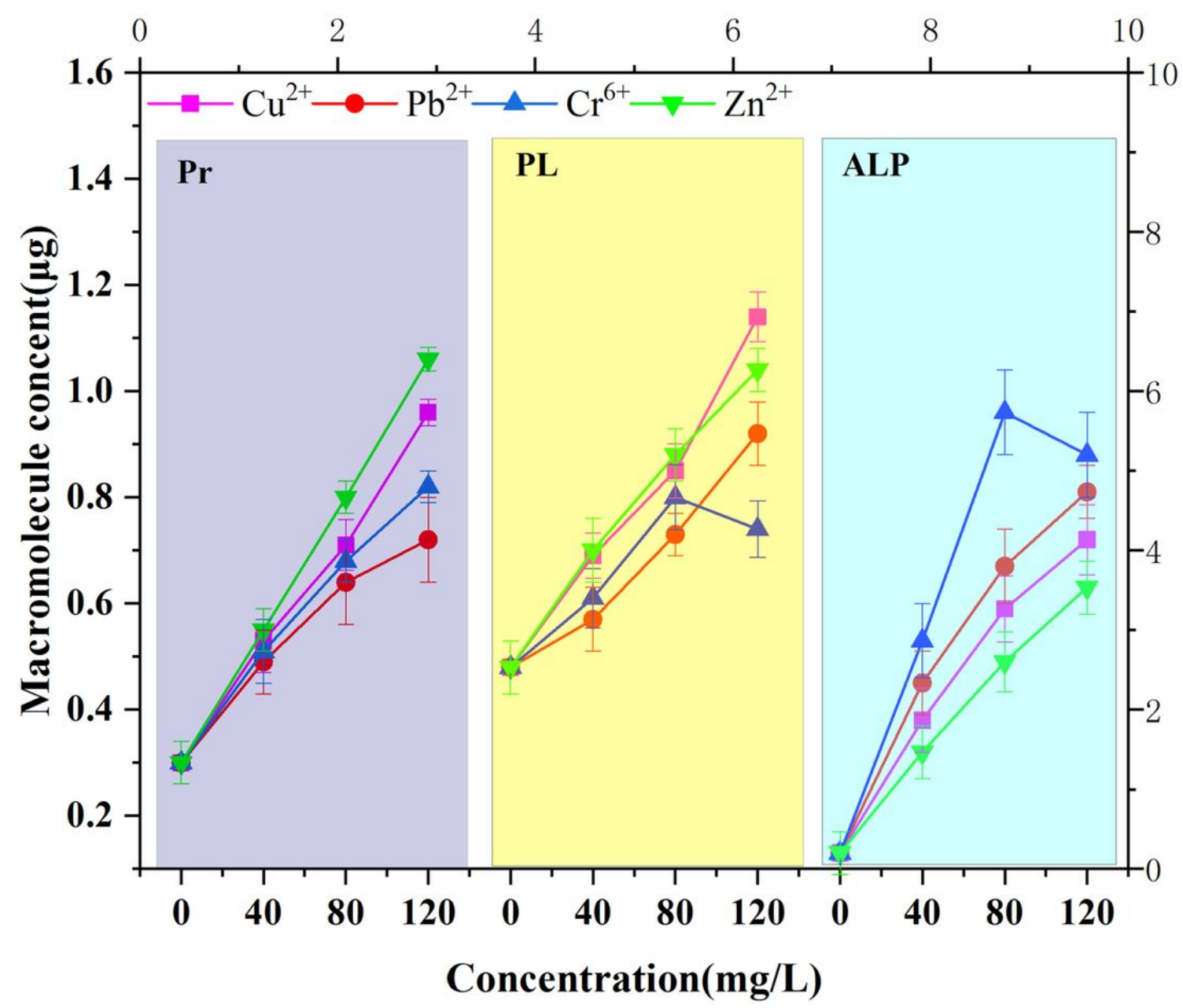

Figure 5

The excessive release of macromolecules such as proteins (Pr), phospholipid (PL), alkaline phosphatase (ALP) will definitely affect the normal function of cells. Without a doubt, with the change of membrane permeability, macromolecules will release to the outside of the cells. In terms of proteins and phospholipid, the variation trend was consistent with the change of membrane permeability

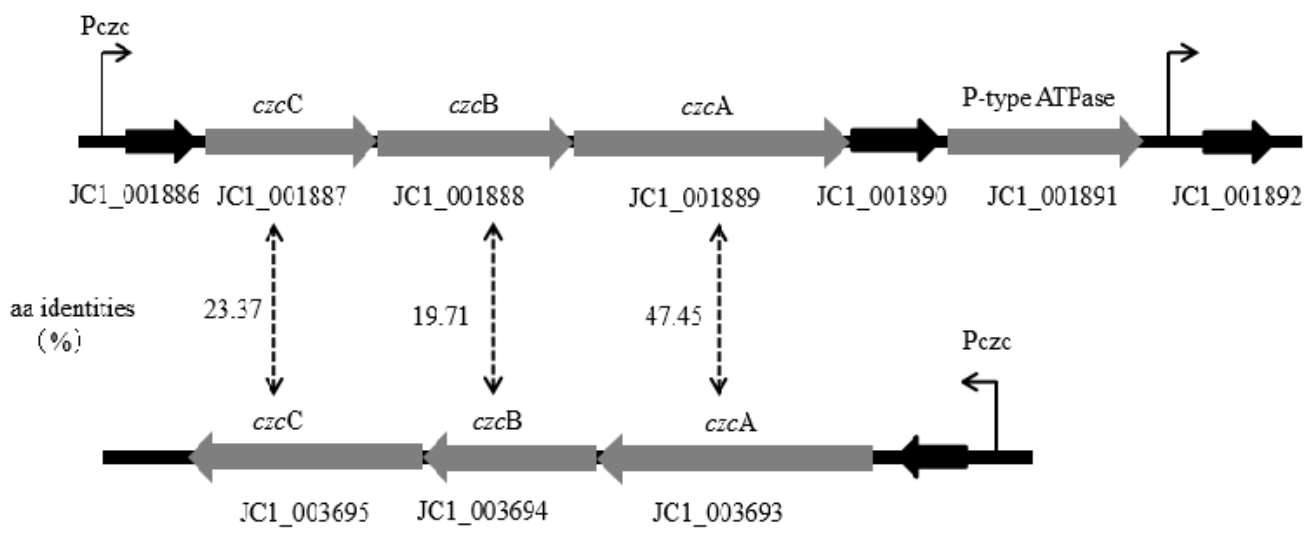

Figure 6

Six heavy-metal efflux proteins were predicted in S. rhizophila JC1 (Table 1). Among them, two types of czcCBA operons (TC\#2.A.6.1.15 and TC\#2.A.6.1.16) form a complete cobalt-zinc-cadmium resistance system homologous to that in Escherichia coli (Tam et al. 2019). czcA is the RND protein, having at least one transmembrane domain and a membrane-spanning helical or beta-stranded domain that embeds in the membrane. czcC is a member of the OMP family 
that forms a trimeric channel and a long helical barrel that allows the export of a variety of substrates in Gram-negative bacteria. In S. rhizophila JC1, the czcCBA operon may transport Cd2+ and Zn2+, as well as Co2+, because there is a gene downstream of czcA that encodes a Cd2+/Zn2+-exporting ATPase

\section{Supplementary Files}

This is a list of supplementary files associated with this preprint. Click to download.

- Graphicalabstract.png

- Additionalfile1.transportproteinssequence.docx

- Fig.S1Relationshipofinvestigatedproteobacteria.png

- TableS1Predictednumberoftransportproteins.docx 